Nevada

Environmental

Restoration

Project

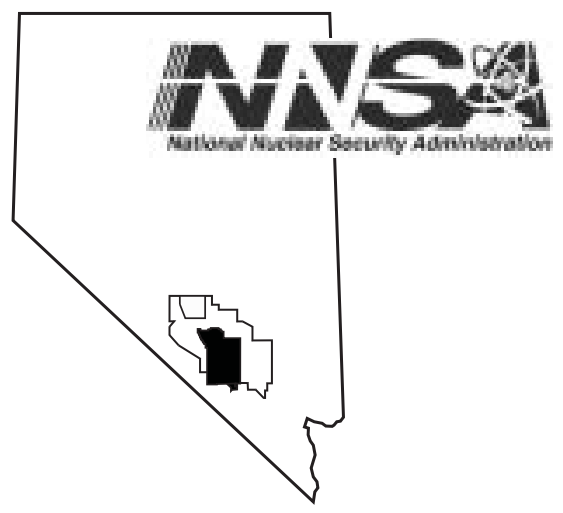

Post-Closure Inspection Report for Corrective Action Unit 333:

U-3auS Disposal Site Annual

Report, Nevada Test Site, Nevada

Controlled Copy No.:

Revision: 0

September 2003

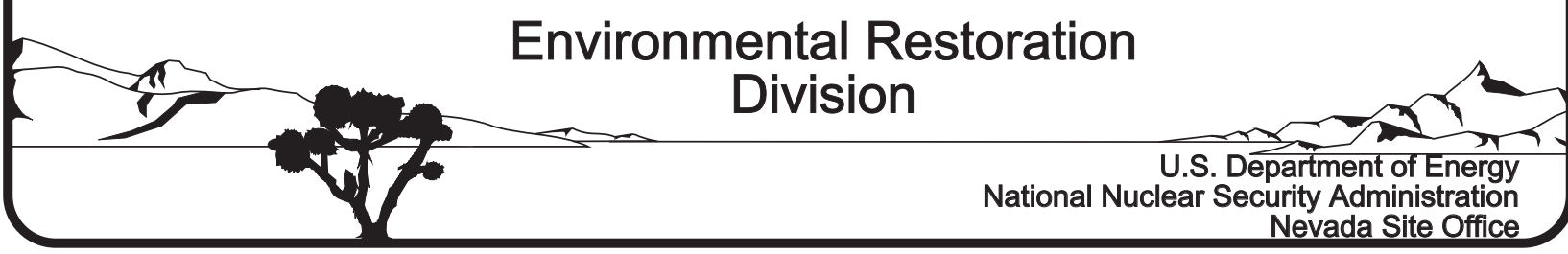




\section{DISCLAIMER STATEMENT}

Reference herein to any specific commercial product, process, or service by trade name, trademark, manufacturer, or otherwise, does not necessarily constitute or imply its endorsement, recommendation, or favoring by the U.S. Government or any agency thereof or its contractors or subcontractors.

\section{AVAILABILITY STATEMENT}

Available for sale to the public from-

U.S. Department of Commerce

National Technical Information Service

5285 Port Royal Road

Springfield, VA 22161-0002

Telephone: 800.553 .6847

Fax: 703.605.6900

E-mail: orders@ntis.gov

Online ordering: http://www.ntis.gov/ordering.htm

Available electronically at http://www.osti.gov/bridge

Available for a processing fee to U.S. Department of Energy and its contractors, in paper, from-

U.S. Department of Energy

Office of Scientific and Technical Information

P.O. Box 62

Oak Ridge, TN 37831-0062

Telephone: 865.576 .8401

Fax: 865.576.5728

E-mail: reports@adonis.osti.gov 


\title{
POST-CLOSURE INSPECTION REPORT FOR CORRECTIVE ACTION UNIT 333: U-3auS DISPOSAL SITE ANNUAL REPORT, NEVADA TEST SITE, NEVADA
}

\author{
Prepared for \\ U.S. Department of Energy \\ National Nuclear Security Administration \\ Nevada Site Office \\ Work Performed Under Contract No. \\ DE-AC08-96NV11718
}

Controlled Copy No.:

Revision: 0

September 2003 
THIS PAGE INTENTIONALLY LEFT BLANK 


\section{POST-CLOSURE INSPECTION REPORT FOR CORRECTIVE ACTION UNIT 333: U-3auS DISPOSAL SITE ANNUAL REPORT, NEVADA TEST SITE, NEVADA}

Approved by: $\frac{\text { SIGNATURE APPROVED }}{\text { Janet L. Appenzeller-Wing, Project Manager }}$ Industrial Sites Project

\footnotetext{
Approved by: SIGNATURE APPROVED Runore C. Wycoff, Division Director Environmental Restoration Division
}

Date: $\quad 8 / 14 / 2003$

Date: $8 / 14 / 2003$ 
THIS PAGE INTENTIONALLY LEFT BLANK 


\section{TABLE OF CONTENTS}

1.0 INTRODUCTION $\ldots \ldots \ldots \ldots \ldots \ldots \ldots \ldots \ldots \ldots \ldots \ldots \ldots \ldots \ldots \ldots \ldots \ldots \ldots$

2.0 INSPECTION RESULTS $\ldots \ldots \ldots \ldots \ldots \ldots \ldots \ldots \ldots \ldots \ldots \ldots \ldots \ldots \ldots \ldots$

3.0 CONCLUSIONS AND RECOMMENDATIONS $\ldots \ldots \ldots \ldots \ldots \ldots \ldots \ldots \ldots \ldots$

\section{ATTACHMENTS}

A. POST-CLOSURE INSPECTION CHECKLISTS

B. FIELD NOTES

C. INSPECTION PHOTOGRAPHS

DISTRIBUTION LIST 
Post Closu re Inspection R eport

CAU 333 - U-3 auS Dispo sal Site

Revis ion: 0

Date: September 2003

\section{THIS PAGE INTENTIONALLY LEFT BLANK}




\subsection{INTRODUCTION}

Post Closu re Inspection R eport CAU 333 - U-3 auS Dispo sal Site

Revis ion: 0

Date: September 2003

The U-3auS Disposal Site Corrective Action Unit (CAU) 333 is a closed construction landfill located in Area 3 of the Nevada Test Site. The closure of this site was approved by the Nevada Division of Environmental Protection (NDEP) in a letter to the U.S. Department of Energy, National Nuclear Security Administration Nevada Operations Office (NNSA/NV) dated June 27, 2001. Post-closure monitoring requirements are described in a letter from NNSA/NV to NDEP dated October 9, 2001, and were approved by the NDEP in a letter from NDEP to NNSA/NV dated November 5, 2001.

Post-closure care consists of the following:

- Semiannual inspections of the unit using an inspection checklist

- $\quad$ Photographic documentation of site conditions

- $\quad$ Field note documentation

- $\quad$ Performing minor site maintenance as necessary

- $\quad$ Preparation and submittal of an annual report

The annual report consists of copies of the inspection checklist, repair records (if any), photographs, and recommendations and conclusions. The Post-Closure Inspection Checklists are provided in Attachment A, a copy of the field notes is found in Attachment B, and copies of the inspection photographs are provided in Attachment C. Field note documentation is not formally required for this $\mathrm{CAU}$, however in order to be consistent with other reports, it has been added to this report.

\subsection{INSPECTION RESULTS}

The post-closure site inspection done in June of 2002 noted several site conditions that required corrective actions. The Post-Closure Report for 2002 recommended activities to repair the noted site conditions (U.S. Department of Energy, National Nuclear Security Administration. 2002. U-3auS Disposal Site Corrective Action Unit 333 Post-Closure Inspection Report. DOE/NV--854. Las Vegas, NV.). Site repairs were made in September of 2002 and included:

- $\quad$ Replacing the existing snow fencing with a more permanent three strand wire rope fence.

- Removal and disposal of construction debris from the site.

- Replacing outdated warning signs with new signs listing pertinent contact information.

- $\quad$ Regrading the road inside the fence line to facilitate future site inspections.

All repair work was documented with photographs included in Attachment C.

The first semiannual inspection of CAU 333 for the annual post-closure monitoring period was performed on December 19, 2002. All problems noted in the June 2002 post-closure inspection were corrected in September 2002. The fence, warning signs and site monuments were in excellent condition. The overall condition of the site was excellent. The inspection was documented on a site inspection form and photographs (Appendix A and C). Note: no field notes were made during this site inspection.

The second semiannual inspection of CAU 333 for the annual post-closure monitoring period was performed on June 26, 2003. Observations indicated that the site had not changed 
significantly since the December 2002 inspection. Site conditions were documented on a site inspection form, field notes, and site photographs (Attachment A, B and C).

\subsection{CONCLUSIONS AND RECOMMENDATIONS}

Continue to inspect the site on a semiannual basis. 


\section{ATTACHMENT A}

\section{POST-CLOSURE INSPECTION CHECKLISTS}


Post Closu re Inspection R eport

CAU 333 - U-3 auS Dispo sal Site

Revis ion: 0

Date: September 2003

\section{THIS PAGE INTENTIONALLY LEFT BLANK}




\section{AREA 3 U3auS DISPOSAL UNIT (CAU 333) INSPECTION FORM}

Inspect the unit and surrounding area. Look for any unusual change in the unit such as accumulation of water, chemical odors, deterioration of structures, etc. Refer to the previous inspection of the unit in order to identify any changes. Inspections, should be completed after a problem is reported by a contractor, NNSA, NDEP, ER or other BN employees. Post Closure Care inspections will be done two times a year.

\section{GENERAL INFORMATION}

1. Date and time of inspection: $12 / 19 / 02$ $14: 00$

2. Facility Owner: Jeffrey L. Smith. Bechtel Nevada Environmental Restoration

3. Reason for inspection: Semiannual: $\underline{\mathbf{X X}}$ Problem Reported: Unusual weather:

Details (Name, organization and telephone number of person reporting problem):

4. Describe weather conditions over the past few weeks (high winds, precipitation, local flooding): Cold and windy. Some snow and rain.

\section{CRATER AREA .}

5. Condition of unit (cracks, subsidence, serious erosion): Good

6. Was gate locked? No __ Yes

Details:

7. Condition of fencing (breaks, tilting):

Good

8. Condition of signs and monuments (missing, fading, damaged, excessive vegetation obscuring signs or monuments):

Good

9. Any trash or other waste in area? No Yes No change $X X$

Details: 


\section{ACTIVITIES}

10. Describe any activities apparent at the time of inspection:

None

\section{AREA SURROUNDING UNIT}

11. Describe any significant changes in the general area (within several hundred feet of the unit) from the previous inspection. Changes can include water in the area, change in land use, storage of materials nearby, soil piles, change in use of the facilty, etc.:

A trail has been developed encircling the unit inside and out.

12. What is the (possible) effect of the change?

The trail should make inspections easier and faster.

13. Other comments or observations:

The old fence and signs have been removed, and a new fence and new signage have been installed since the June inspection.

14. Recommendations:

Continue inspections as scheduled.

15. Does the finding(s) of this inspection require another inspection prior to the scheduled semiannual inspection? No $X X$ Yes If yes, date of next inspection:

The ER Project Manager and Task Manager must be notified of significant changes upon return to the office.

Inspected by (print): Jim Trayner Signed:

Names of other persons on inspection (print):

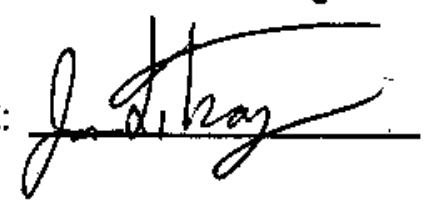

Date: $12 / 19 / 02$

David Nacht 


\section{AREA 3 U3auS DISPOSAL UNIT (CAU 333) \\ INSPECTION FORM}

Inspect the unit and surrounding area. Look for any unusual change in the unit such as accumulation of water, chemical odors, deterioration of structures, etc. Refer to the previous inspection of the unit in order to identify any changes. Inspections, should be completed after a problem is reported by a contractor, NNSA, NDEP, ER or other BN employees. Post Closure Care inspections will be done two times a year.

\section{GENERAL INFORMATION}

1. Date and time of inspection: $\quad 06 / 26 / 03 \quad 11: 10$

2. Facility Owner: Jeff Smith. Bechtel Nevada Environmental Restoration

3. Reason for inspection: Semiannual:

Problem Reported: ___ Unusual weather:

Details (Name, organization and telephone number of person reporting problem):

4. Describe weather conditions over the past few weeks (high winds, precipitation, local flooding): Clear, Hot

\section{CRATER AREA}

5. Condition of unit (cracks, subsidence, serious erosion): No Change

6. Was gate locked? No ___ Yes _..

Detalls:

7. Condition of fencing (breaks, tilting):

Fences were in good condition, no change.

8. Condition of signs and monuments (missing, fading, damaged, excessive vegetation obscuring

signs or monuments):

Monuments were in good condition, no change.

9. Any trash or other waste in area? No Yes No change

Details: 


\section{ACTIVITIES}

10. Describe any activities apparent at the time of inspection:

No new activities.

\section{AREA SURROUNDING UNIT}

11. Describe any significant changes in the general area (within several hundred feet of the unit) from the previous inspection. Changes can include water in the area, change in land use, storage of

No change. materials nearby, soil piles, change in use of the facility, etc.:

12. What is the (possible) effect of the change?

N/A

13. Other comments or observations:

None

14. Recommendations:

Continue inspections as scheduled.

15. Does the finding(s) of this inspection require another inspection prior to the scheduled semiannual inspection? No $\mathrm{X}$ Yes If yes, date of next inspection:

The ER Project Manager and Task Manager must be notified of significant changes upon retum to the office.

Inspected by (print):

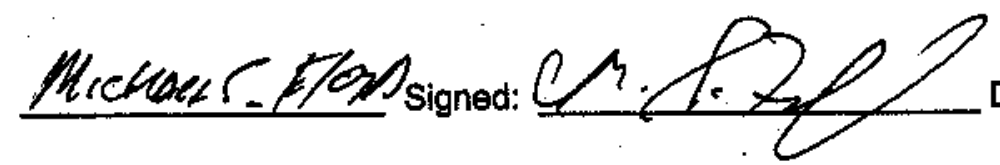
Date:

Names of other persons on inspection (print): 


\section{ATTACHMENT B}

\section{FIELD NOTES}


Post Closu re Inspection R eport

CAU 333 - U-3 auS Dispo sal Site

Revis ion: 0

Date: September 2003

\section{THIS PAGE INTENTIONALLY LEFT BLANK}


70 lILt

Work continued from Page

RenA INTERTES

BOOK NO.

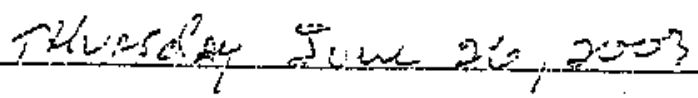

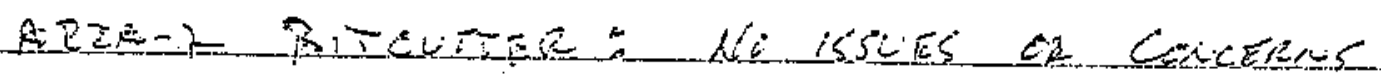

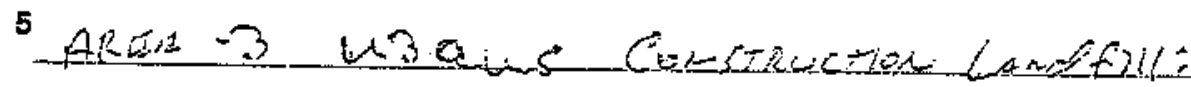

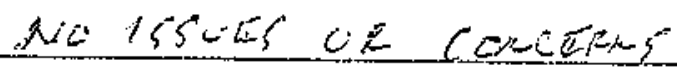

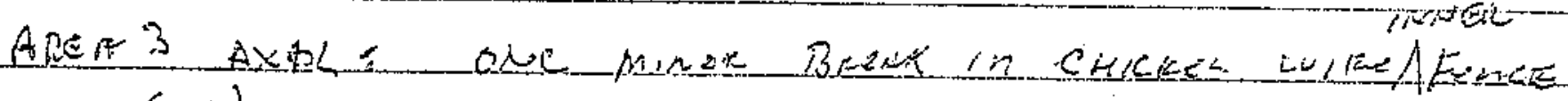

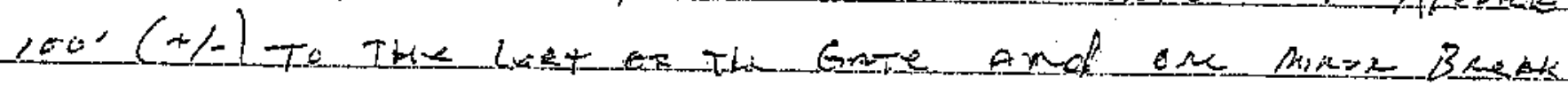

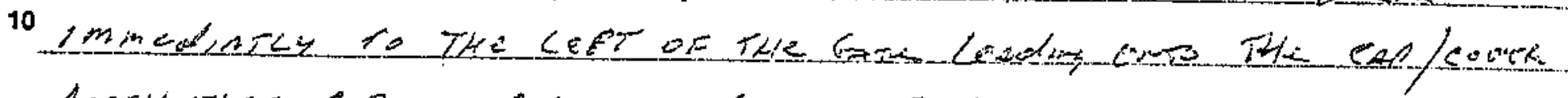

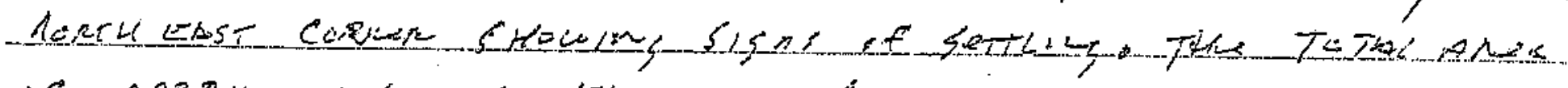

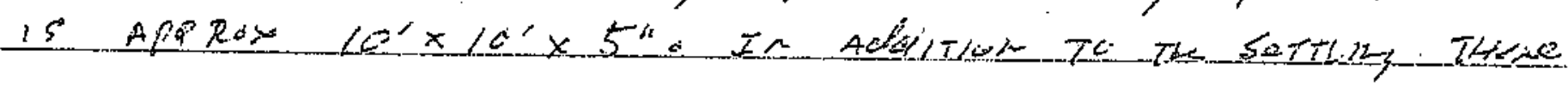

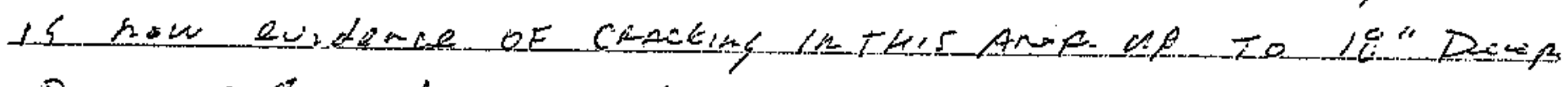

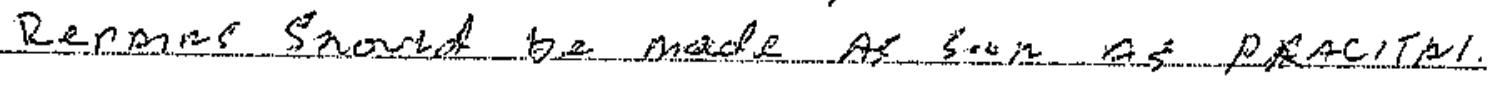

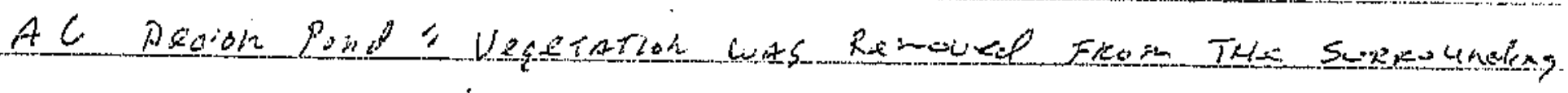

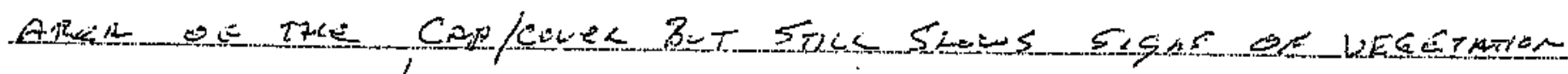

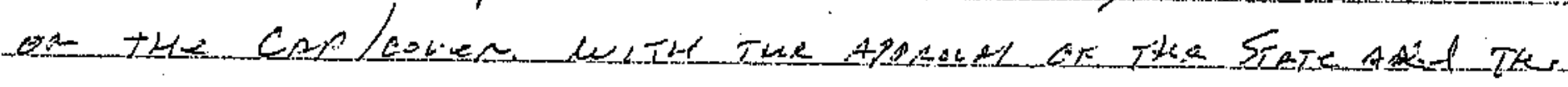

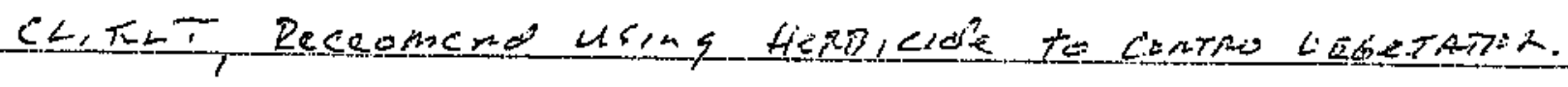

20

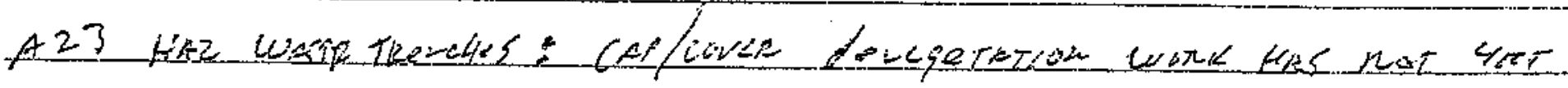

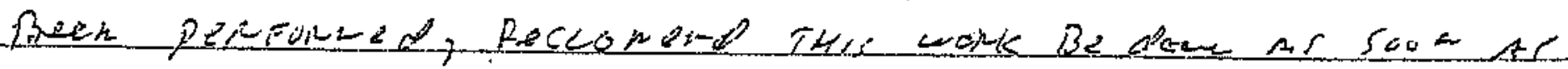
Pentad?

25

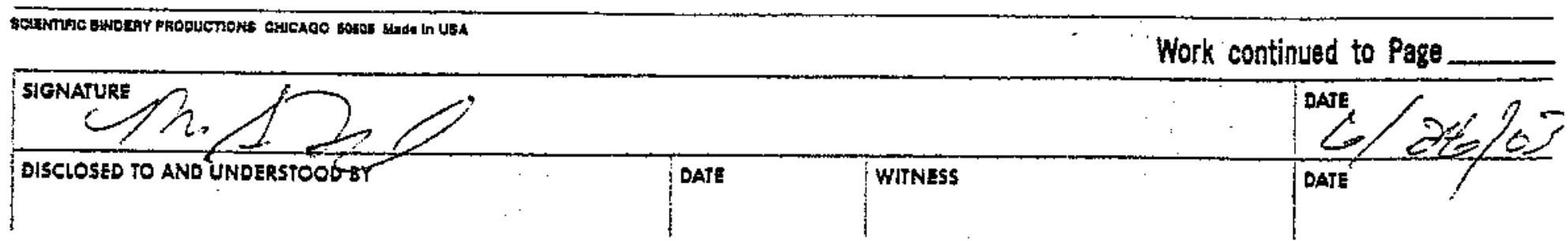


Post Closu re Inspection R eport

CAU 333 - U-3 auS Dispo sal Site

Revis ion: 0

Date: September 2003

\section{THIS PAGE INTENTIONALLY LEFT BLANK}




\section{ATTACHMENT C}

\section{INSPECTION PHOTOGRAPHS}


Post Closu re Inspection R eport

CAU 333 - U-3 auS Dispo sal Site

Revis ion: 0

Date: September 2003

\section{THIS PAGE INTENTIONALLY LEFT BLANK}




\section{PHOTOGRAPH LOG}

\begin{tabular}{||c|l|l||}
\hline \multicolumn{1}{|c}{$\begin{array}{c}\text { PHOTO } \\
\text { NUMBER }\end{array}$} & \multicolumn{1}{l||}{ DATE } & \multicolumn{1}{l||}{ DESCRIPTION } \\
\hline 1 & $9 / 19 / 2002$ & Gate to unit. \\
\hline 2 & $9 / 19 / 2002$ & View from gate looking northwest along fence line. \\
\hline 3 & $9 / 19 / 2002$ & View from gate looking southeast along fence line. \\
\hline 1 & $12 / 19 / 2002$ & Gate to unit. \\
\hline 2 & $12 / 19 / 2002$ & View looking north from center of unit. \\
\hline 3 & $12 / 19 / 2002$ & View looking east from center of unit. \\
\hline 4 & $12 / 19 / 2002$ & View looking south from center of unit. \\
\hline 5 & $12 / 19 / 2002$ & View looking west from center of unit. \\
\hline 6 & $12 / 19 / 2002$ & View from gate looking northwest along fence line. \\
\hline 7 & $12 / 19 / 2002$ & View from gate looking southeast along fence line. \\
\hline 8 & $12 / 19 / 2002$ & View looking south along northern boundary. \\
\hline 9 & $12 / 19 / 2002$ & View looking west along eastern boundary. \\
\hline 10 & $12 / 19 / 2002$ & View looking north along southern boundary. \\
\hline 11 & $12 / 19 / 2002$ & View looking east from western boundary. \\
\hline 1 & $6 / 26 / 2003$ & Gate to unit. \\
\hline 2 & $6 / 26 / 2003$ & View from gate looking northwest along fence line. \\
\hline 3 & $6 / 26 / 2003$ & View from gate looking southeast along fence line. \\
\hline 4 & $6 / 26 / 2003$ & View looking south along northern boundary. \\
\hline 5 & $6 / 26 / 2003$ & View looking west along eastern boundary. \\
\hline \hline & & \\
\hline \hline
\end{tabular}


Post Closu re Inspection R eport

CAU 333 - U-3 auS Dispo sal Site

Revis ion: 0

Date: September 2003

\section{THIS PAGE INTENTIONALLY LEFT BLANK}




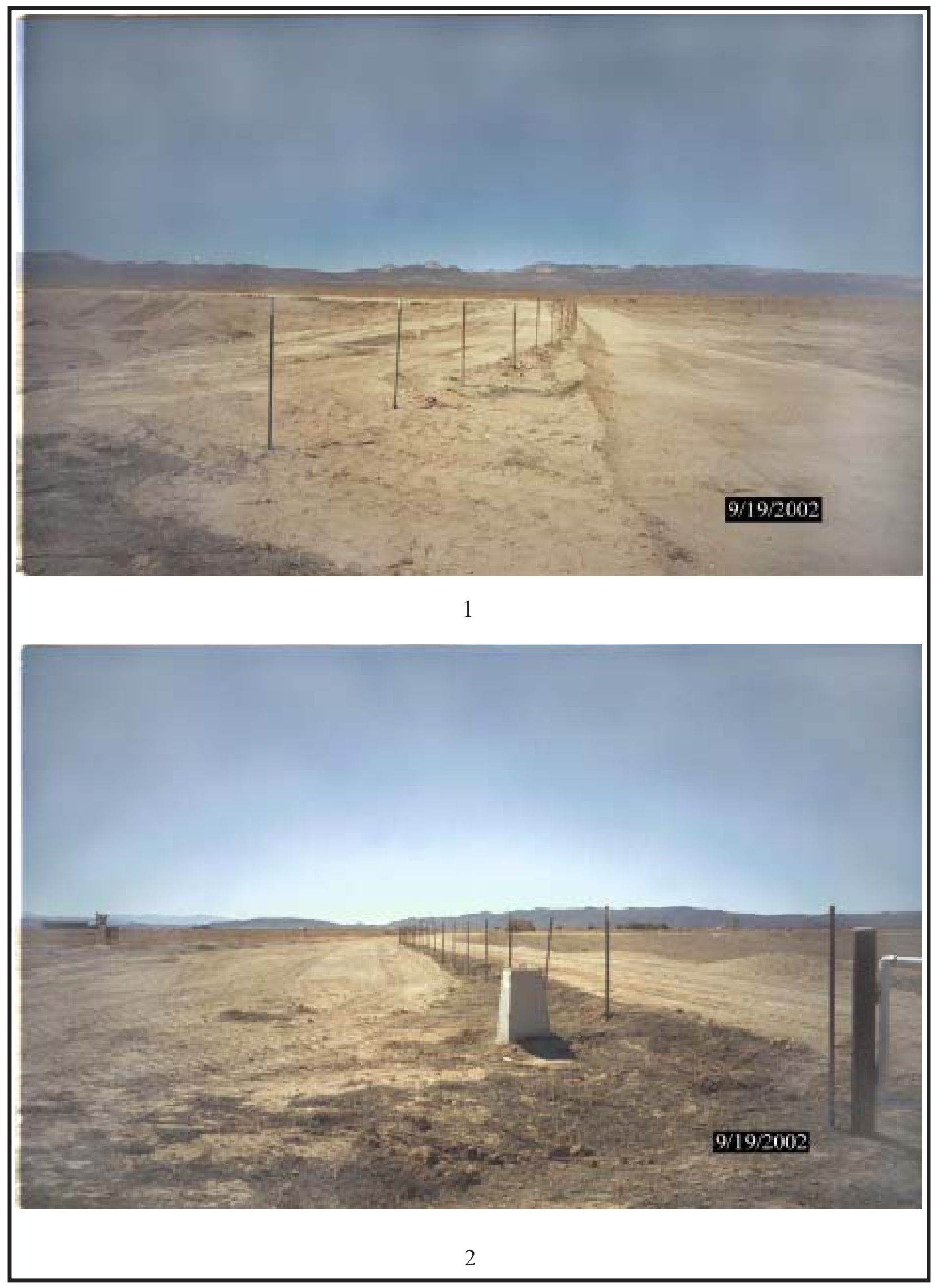

C-3 


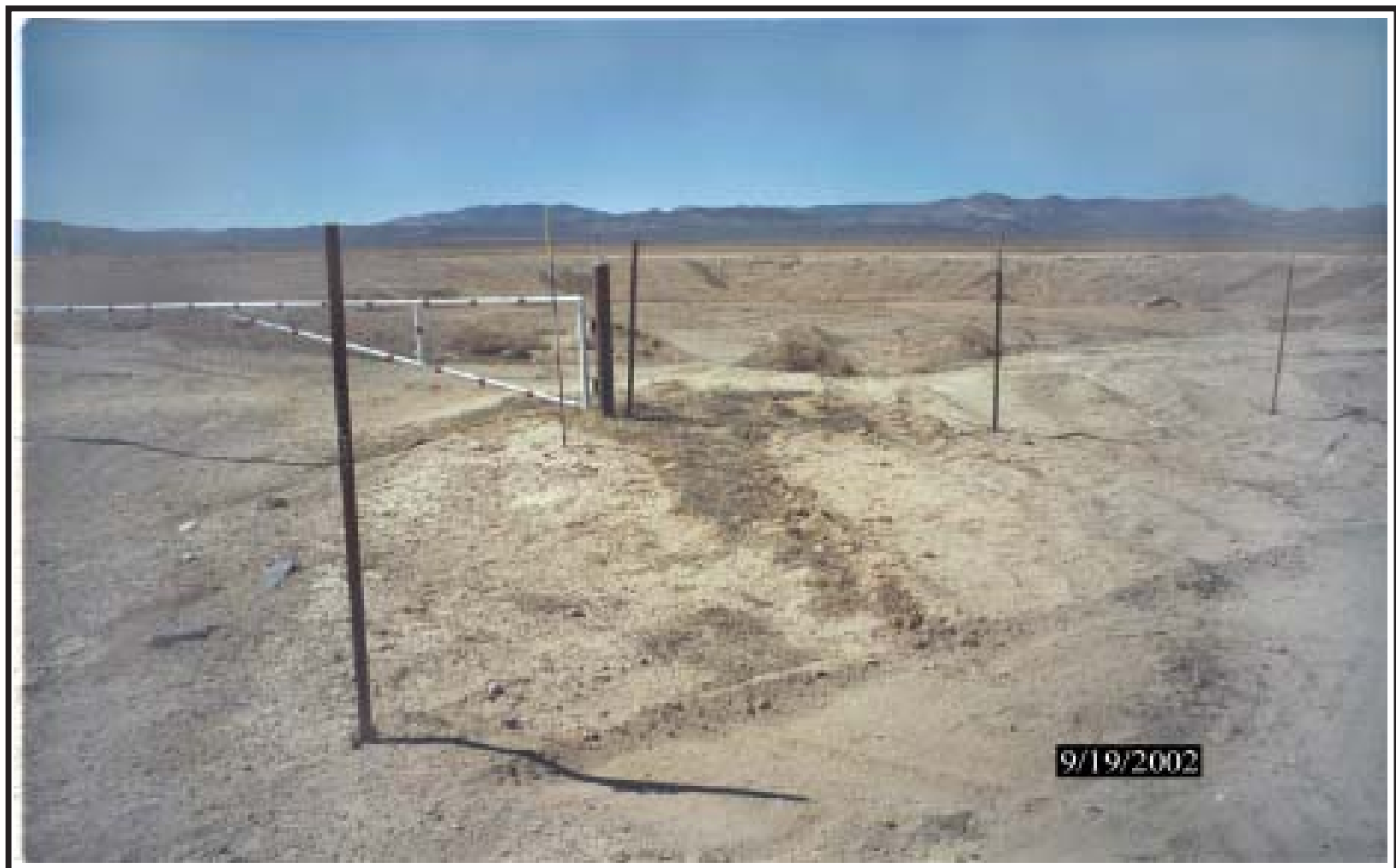




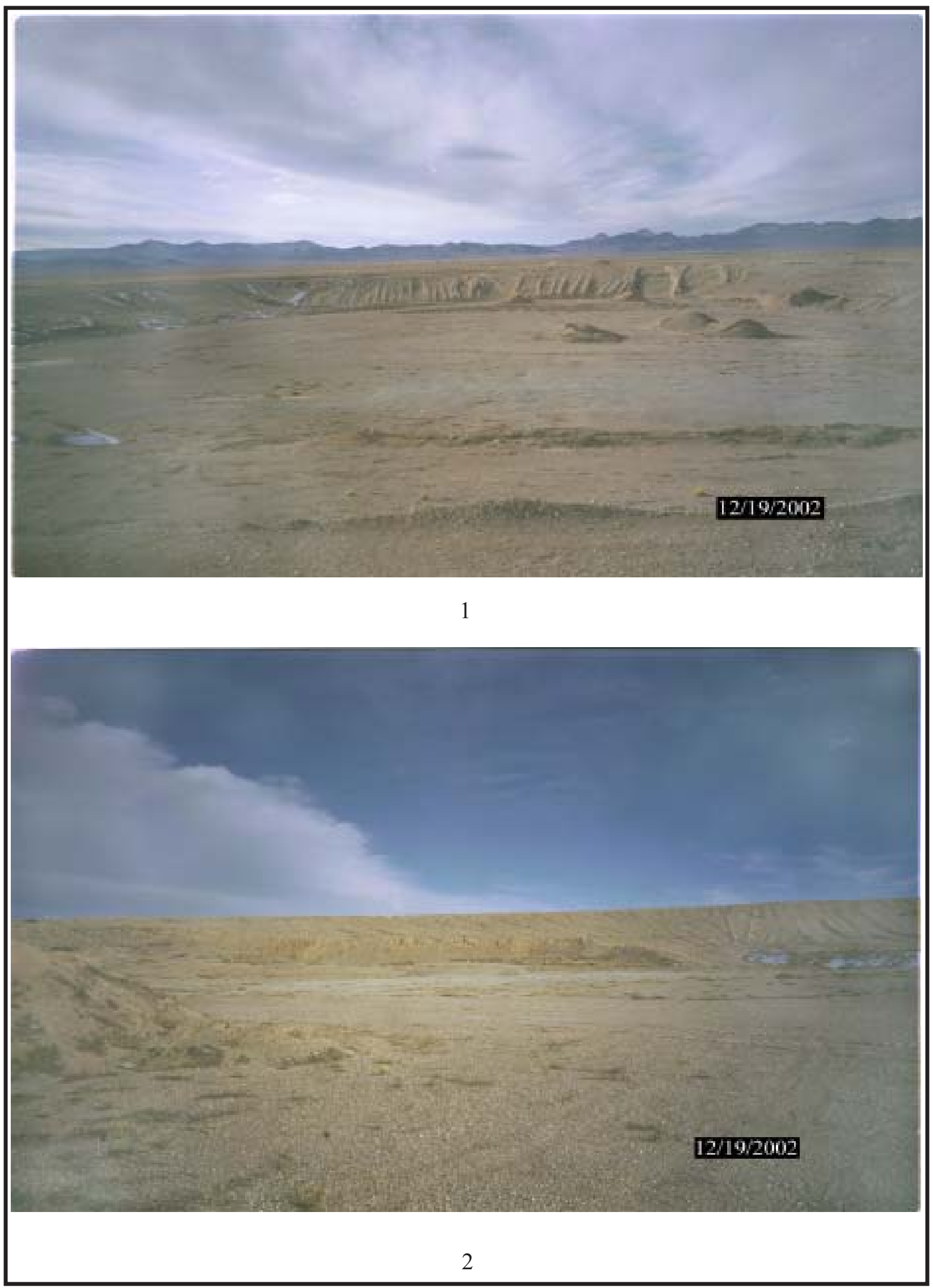

C-5 


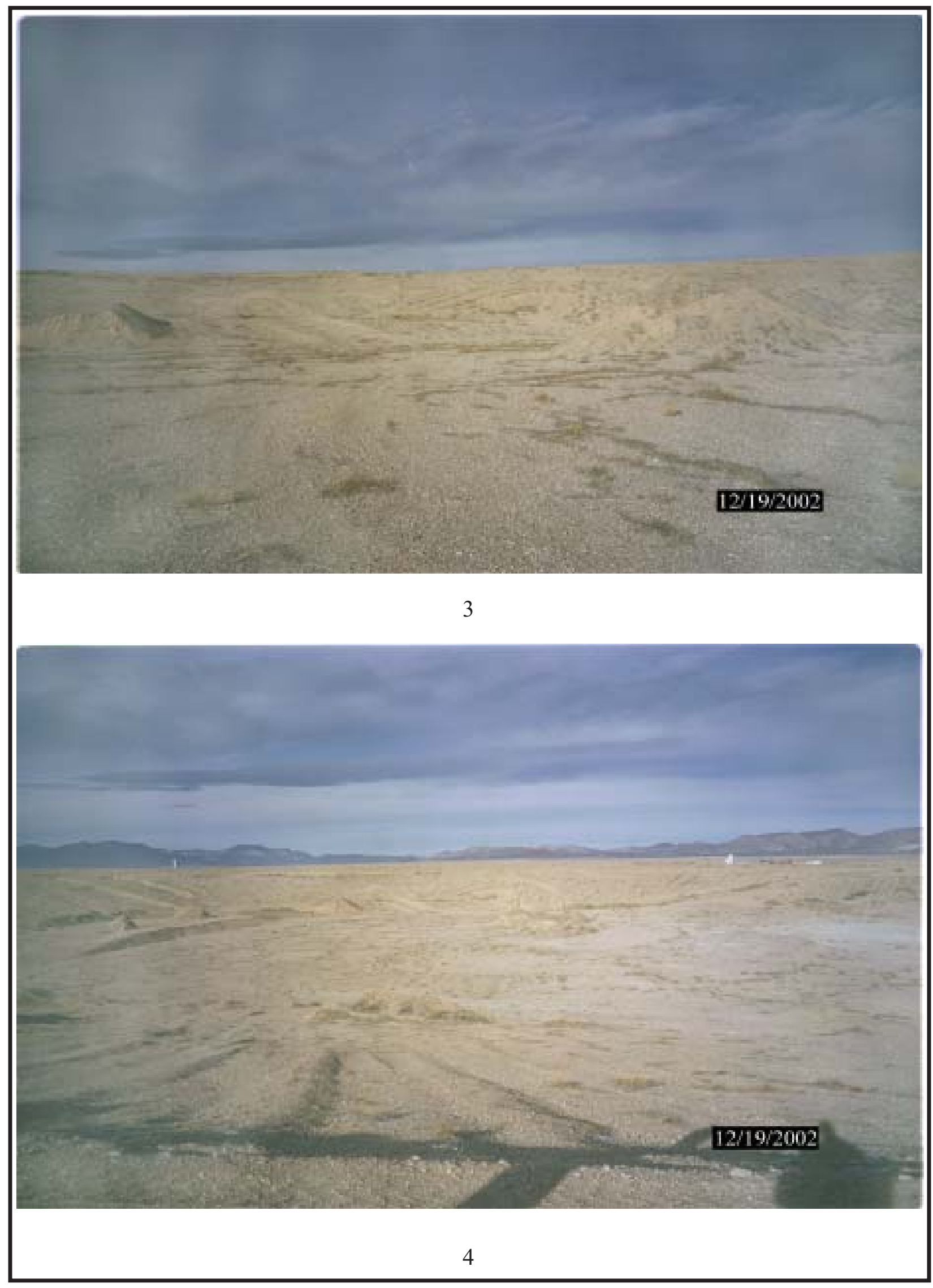

C-6 


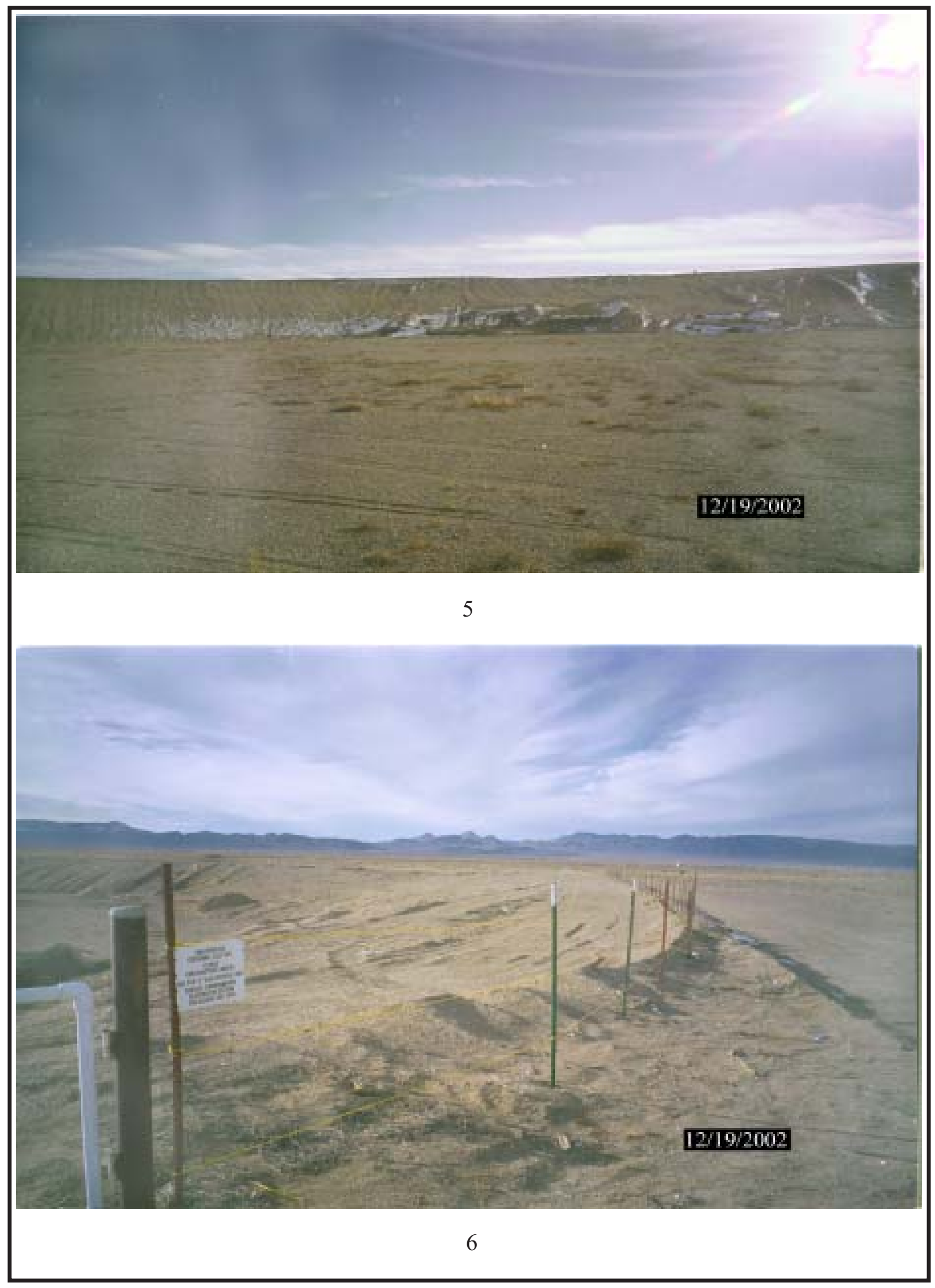




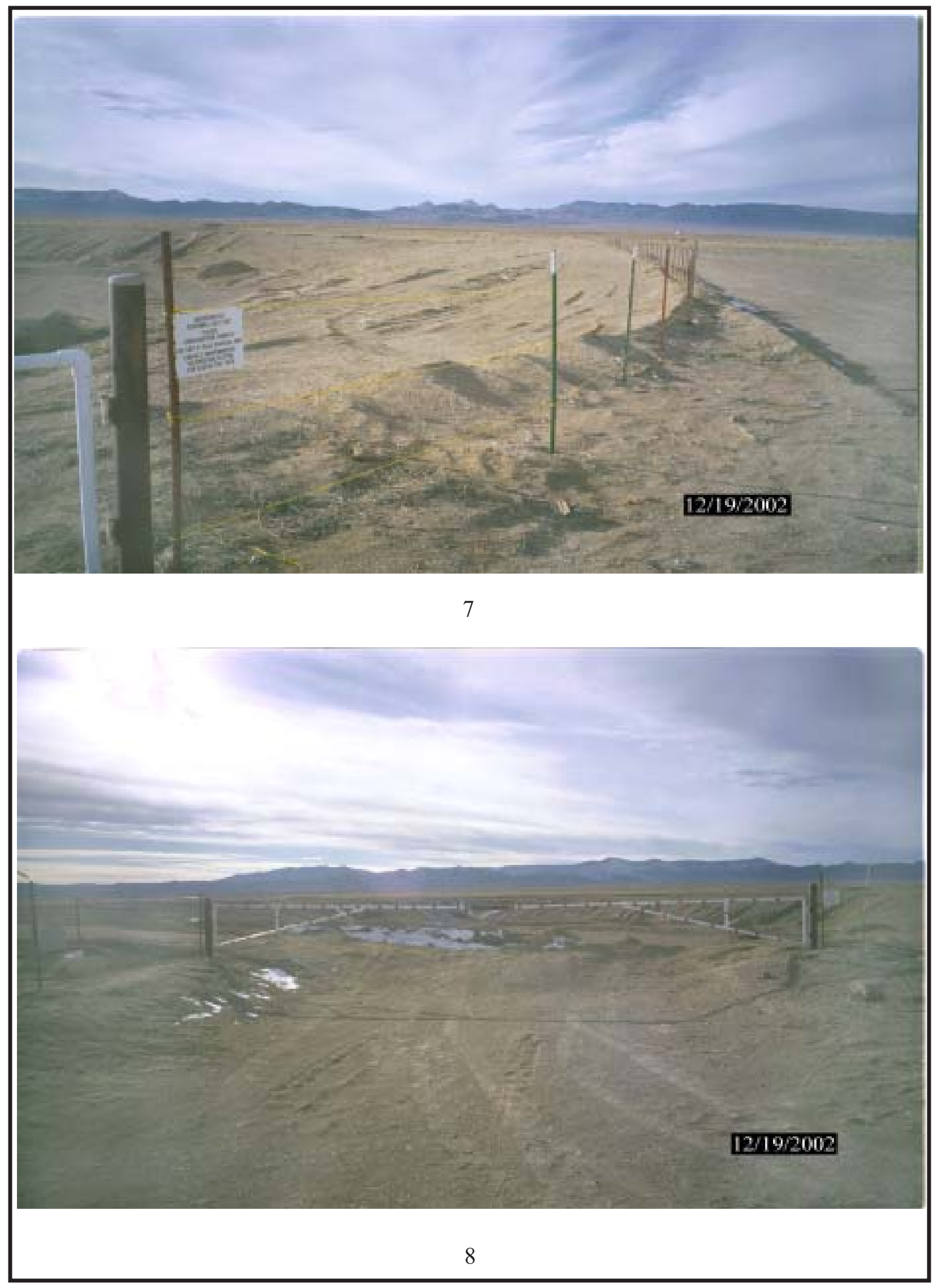




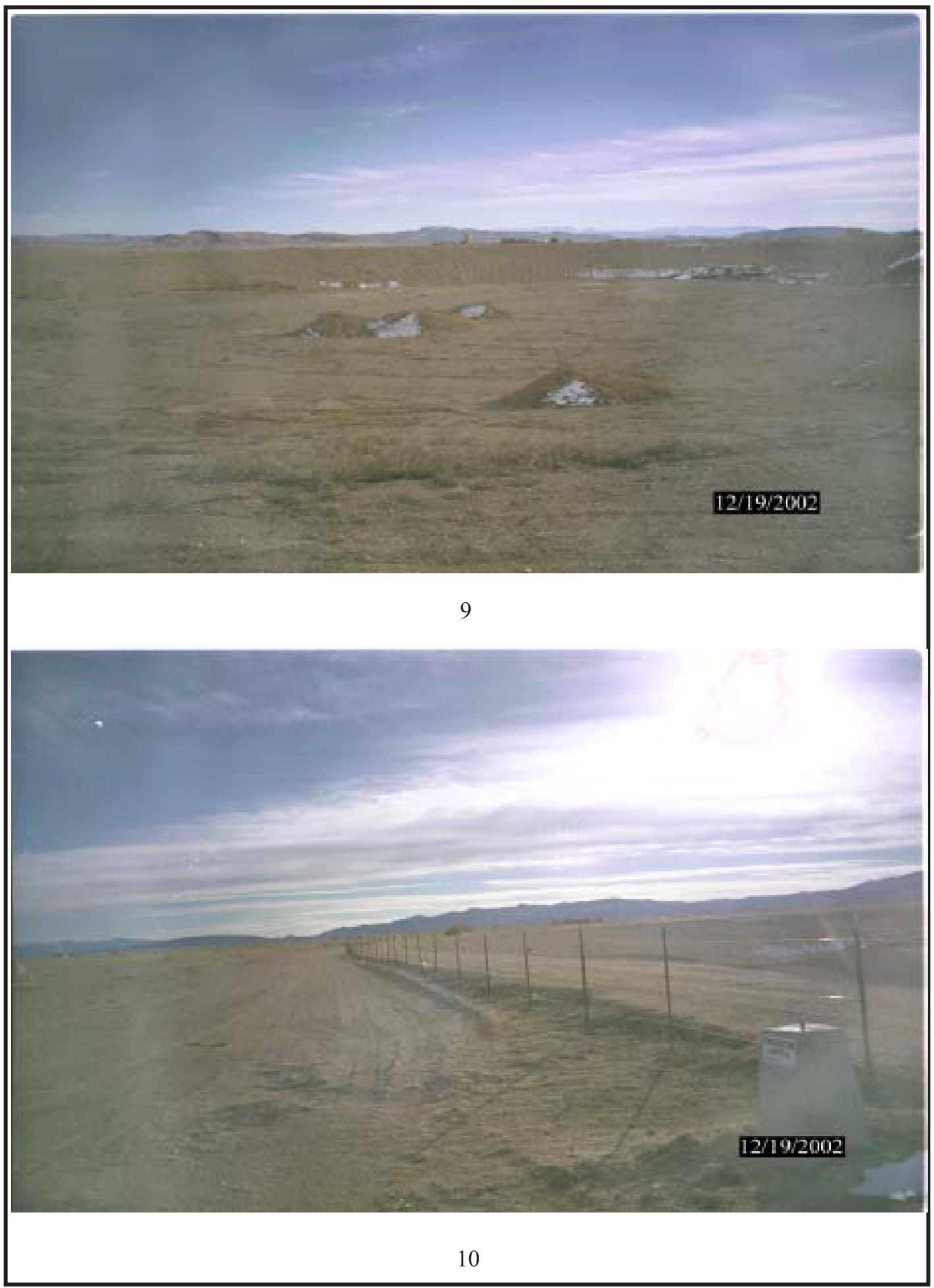




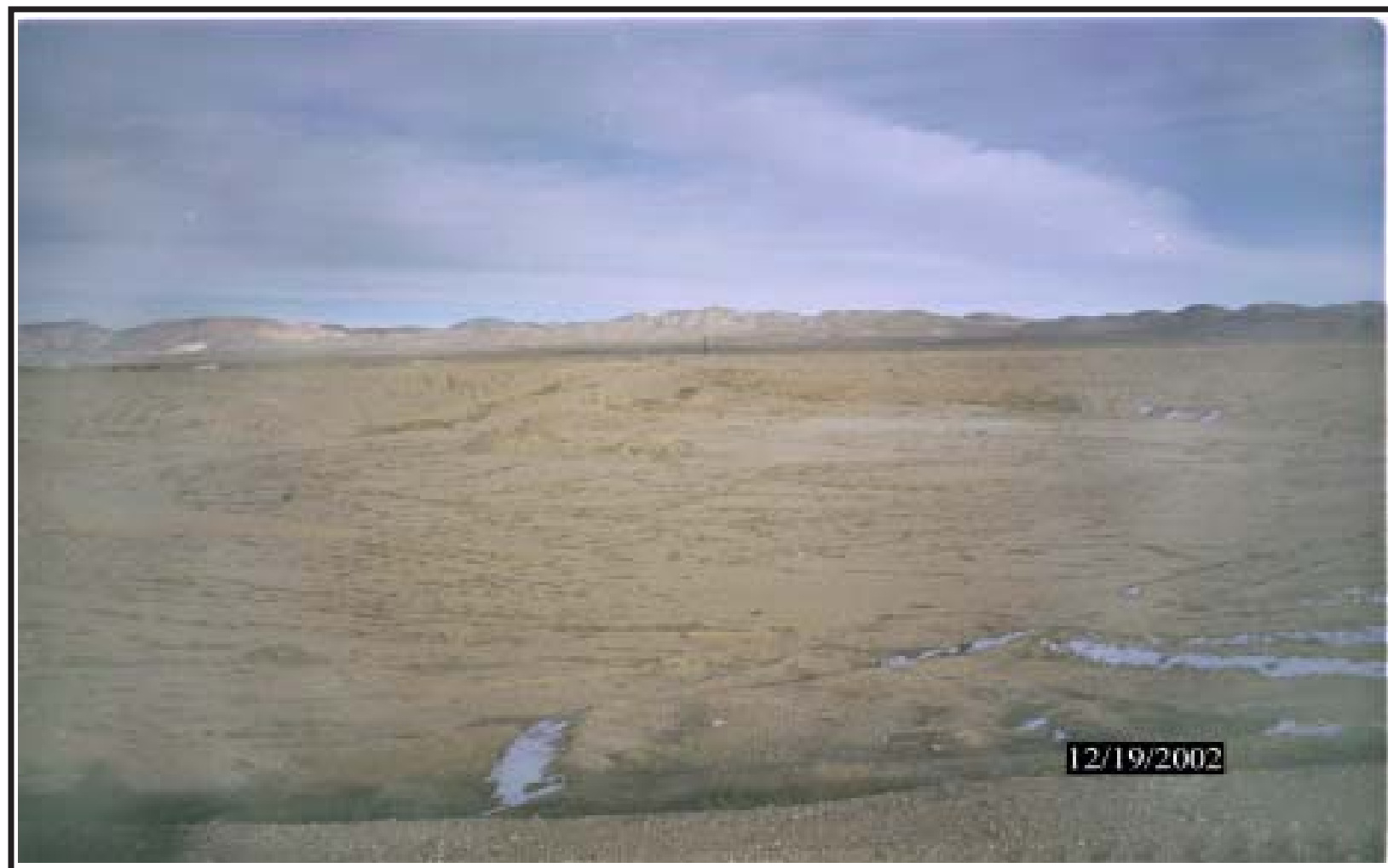




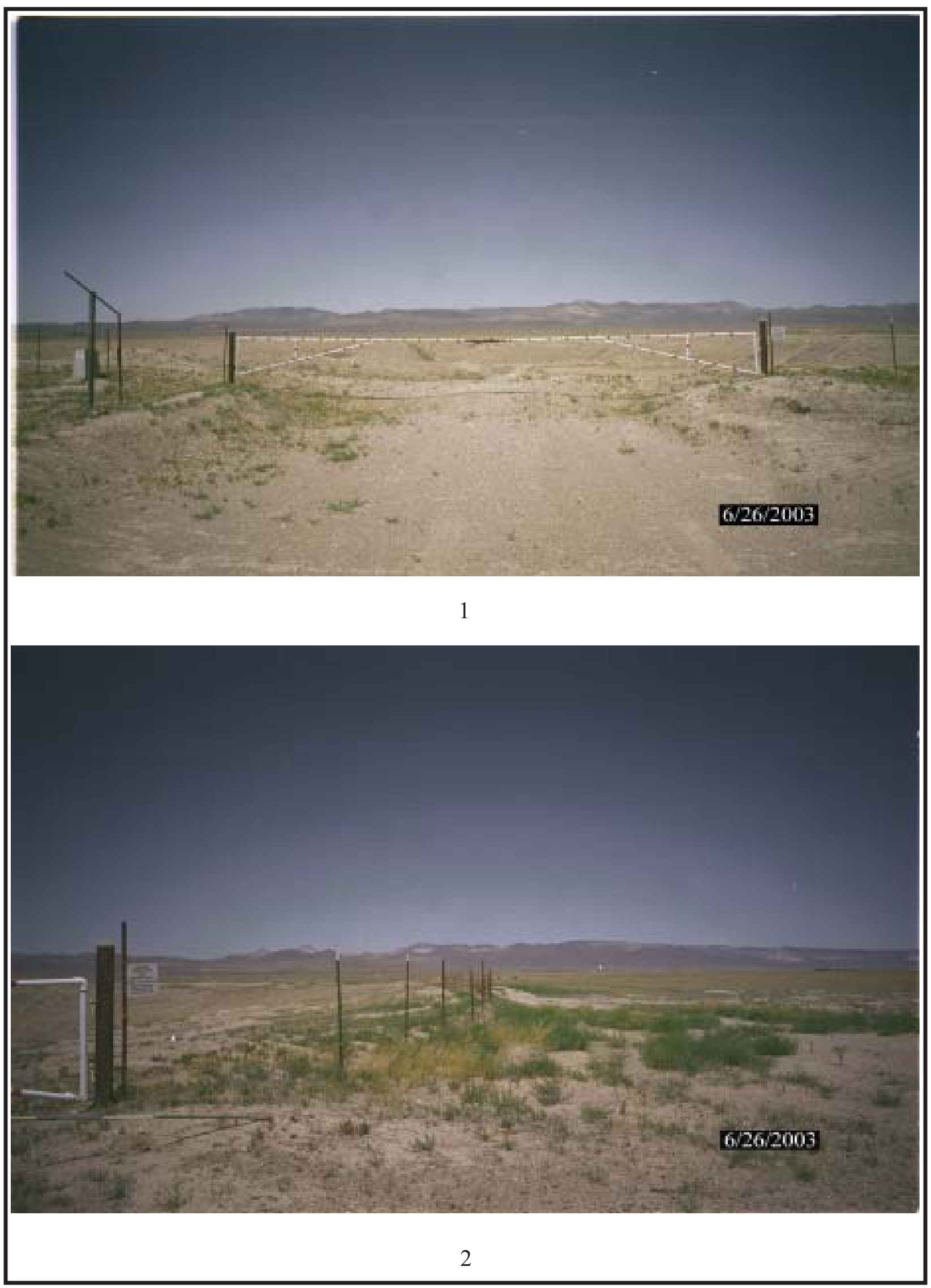

C-11 


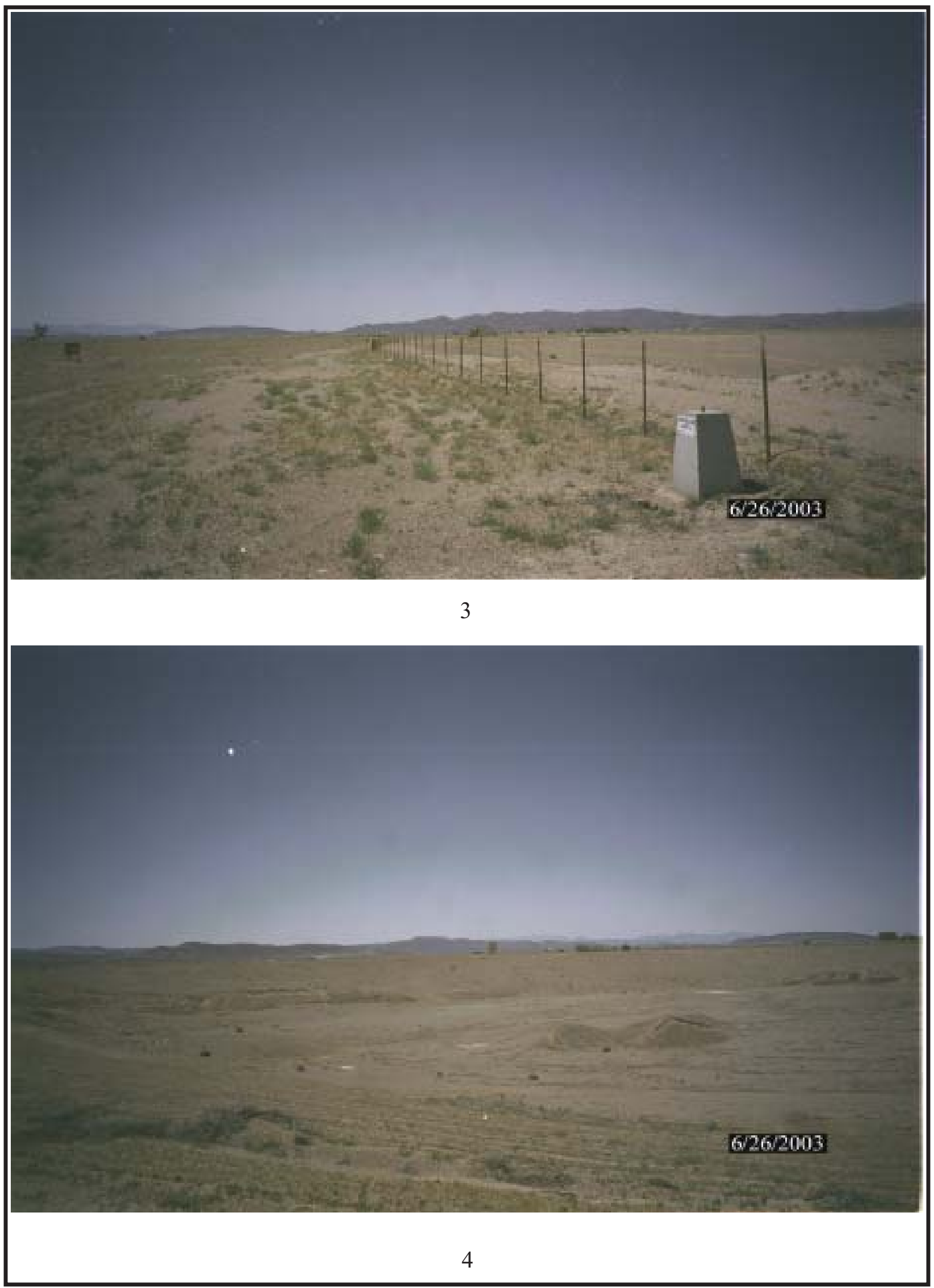

C-12 


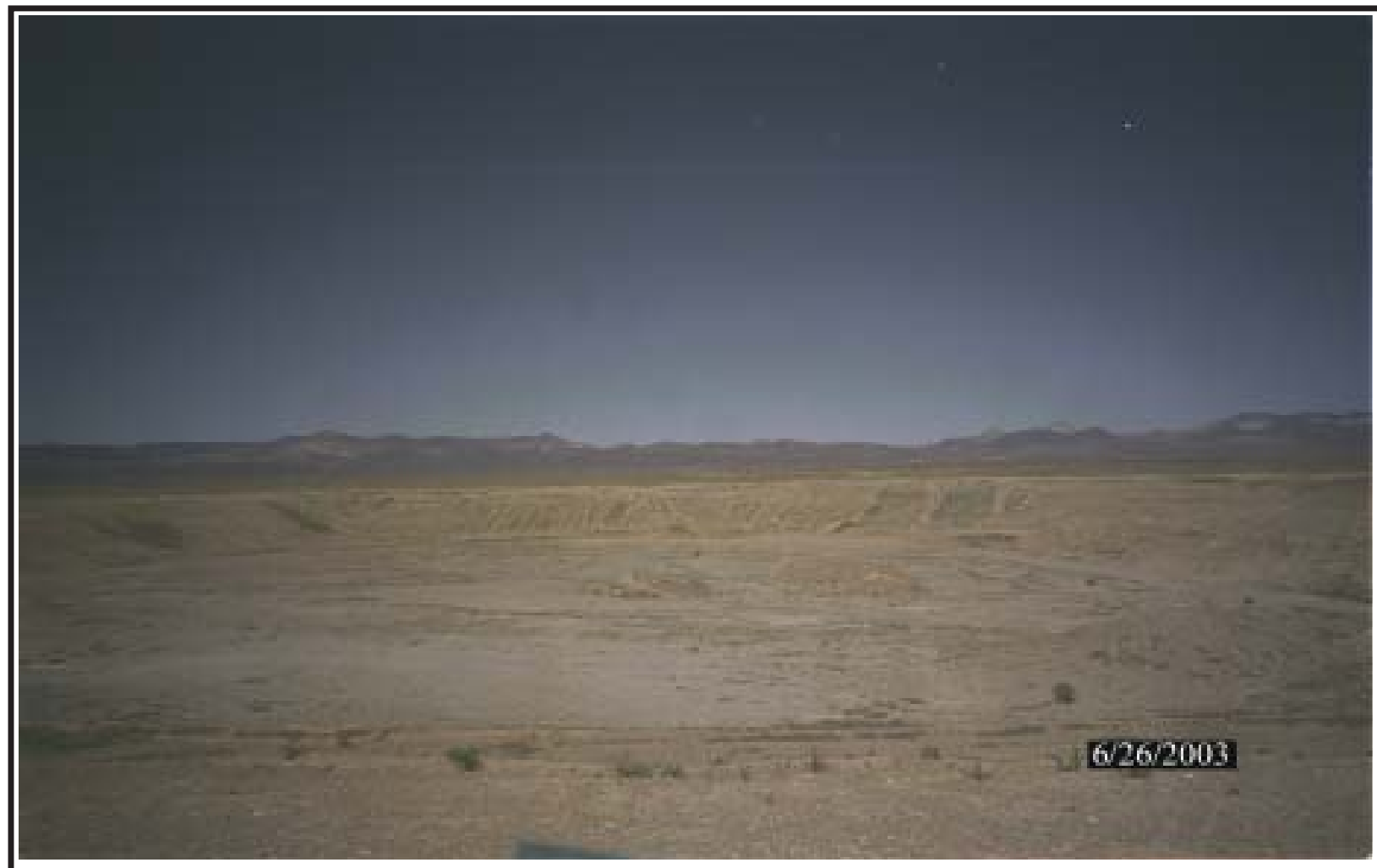


Post Closu re Inspection R eport

CAU 333 - U-3 auS Dispo sal Site

Revis ion: 0

Date: September 2003

\section{DISTRIBUTION LIST}


Post Closu re Inspection R eport

CAU 333 - U-3 auS Dispo sal Site

Revis ion: 0

Date: September 2003

\section{THIS PAGE INTENTIONALLY LEFT BLANK}




\section{DISTRIBUTION LIST}

*Provide copy of initial distribution of all revisions; others receive NDEP-approved revision only.

\section{$\underline{\text { Nevada Division of Environmental Protection }}$}

Paul Liebendorfer

$1($ Controlled)*

Bureau of Federal Facilities

Division of Environmental Protection

333 W. Nye Lane, Room 138

Carson City, NV 89706-0866

Donald Elle

Bureau of Federal Facilities

$1($ Controlled)*

Division of Environmental Protection

1771 East Flamingo Road, Suite 121-A

Las Vegas, NV 89119-0837

\section{U.S. Department of Energy}

Janet Appenzeller-Wing

1 (Uncontrolled)*

Environmental Restoration Division

U.S. Department of Energy

National Nuclear Security Administration

Nevada Site Office

P.O. Box 98518, M/S 505

Las Vegas, NV 89193-8518

Kevin Cabble

Environmental Restoration Division

1 (Uncontrolled)*

U.S. Department of Energy

National Nuclear Security Administration

Nevada Site Office

P.O. Box 98518, M/S 505

Las Vegas, NV 89193-8518

Sabrina Lawrence

Environmental Restoration Division

1 (Controlled)*

U.S. Department of Energy

National Nuclear Security Administration

Nevada Site Office

P.O. Box 98518, M/S 505

Las Vegas, NV 89193-8518 


\section{DISTRIBUTION LIST (continued)}

\section{U.S. Department of Energy (continued)}

U.S. Department of Energy

National Nuclear Security Administration

Nevada Site Office

Southern Nevada Public Reading Facility

$\mathrm{C} / \mathrm{O}$ Nuclear Testing Archive

P.O. Box 98521, M/S 400

Las Vegas, NV 89193-8521

U.S. Department of Energy

National Nuclear Security Administration

Nevada Site Office

Technical Library

P.O. Box 98518

Las Vegas, NV 89193-8518

U.S. Department of Energy

Office of Scientific and Technical Information

P.O. Box 62

Oak Ridge, TN 37831-0062

\section{Bechtel Nevada}

Correspondence Control

Bechtel Nevada

P.O. Box 98521, M/S CF008

Las Vegas, NV 89193-8521

Environmental Management Library

Bechtel Nevada

P.O. Box 98521, M/S NLV080

Las Vegas, NV 89193-8521

Kevin Campbell

Bechtel Nevada

P.O. Box 98521, M/S NTS306

Las Vegas, NV 89193-8521

Wayne Johnson

Bechtel Nevada

P.O. Box 98521, M/S NLV080

Las Vegas, NV 89193-8521
1 (Controlled) \&

1 (Uncontrolled)

1 (Uncontrolled) 


\section{DISTRIBUTION LIST (continued)}

\section{$\underline{\text { Bechtel Nevada (continued) }}$}

Kraig Knapp

1 (Uncontrolled)*

Bechtel Nevada

P.O. Box 98521, M/S NTS306

Las Vegas, NV 89193-8521

Patrick Morris

1 (Uncontrolled)*

Bechtel Nevada

P.O. Box 98521, M/S NTS306

Las Vegas, NV 89193-8521

Glenn Richardson

1 (Uncontrolled)*

Bechtel Nevada

P.O. Box 98521, M/S NTS306

Las Vegas, NV 89193-8521

Shaw Environmental, Inc.

FFACO Coordinator

1 (Controlled)

Shaw Environmental

P.O. Box 93838, M/S 439

Las Vegas, NV 89193-3838

John Stokowski

1 (Uncontrolled)*

Shaw Environmental

P.O. Box 93838, M/S 439

Las Vegas, NV 89193-3838

\section{State of Nevada}

Manager, Northern Nevada

FFACO Public Reading Facility

1 (Uncontrolled)

Nevada State Library and Archives Federal Publications

100 North Stewart Street

Carson City, NV 89701-4285 
Post Closu re Inspection R eport

CAU 333 - U-3 auS Dispo sal Site

Revis ion: 0

Date: September 2003

\section{THIS PAGE INTENTIONALLY LEFT BLANK}

